\title{
Trudne żałoby
}

\author{
Wywiad z Carine Trevisan \\ przeprowadzony w języku francuskim i przetłumaczony \\ na język polski przez Piotra Sadkowskiego*
}

DOI: http://dx.doi.org/10.12775/LC.2018.039

Carine Trevisan, profesor literatury na Uniwersytecie Paris VII - Denis Diderot, jest autorką prac na temat I wojny, odznaczających się ujęciem interdyscyplinarnym

Redaktor: W książce AURÉLIEN d'Aragon. Un « nouveau mal du siècle 》 (AURÉLIEN Aragona. „Nowa choroba wieku”), wydanej w roku 1996, analizuje Pani problem zaburzenia tożsamości i systemu etycznego człowieka naznaczonego doświadczeniem Wielkiej Wojny, które uniemożliwia powrót do „normalnego” życia w sferze afektywnej i społecznej ${ }^{1}$. Czy mogłaby Pani wyjaśnić, na czym w tym kontekście polega zjawisko „choroby wieku”? W jakiej mierze można mówić o analogiach pomiędzy bohaterami literatury XIX wieku, zmagającymi się z Historią, a postaciami ludzi dotkniętych traumą I wojny? Czy jest uzasadnionym dostrzeganie tu francuskiego odpowiednika Lost Generation? Jacy jeszcze bohaterowie, obok Aureliana, czy też tytułowego Gilles’a z powieści Drieu La Rochelle’a, albo Bardamu z Podróży do kresu nocy Céline'a ${ }^{2}$, należeliby do tego kręgu?

Carine Trevisan (dalej C. T.): Analogie pomiędzy postaciami z literatury XIX wieku dotkniętymi „chorobą wieku” a ocalałymi z Wielkiej Wojny są odległe. W XIX wieku choroba wieku łączyła się z poczuciem bycia urodzonym po epopei napoleońskiej, „na ruinach świata”, jak to określał Alfred de Musset w Spowiedzi dziecięcia wieku³. Musset kreśli portret młodzieży „w chmurnej zadumie”, osieroconej po epickich marzeniach, zawieszonej

\footnotetext{
" Dr hab., adiunkt w Katedrze Filologii Romańskiej Uniwersytetu Mikołaja Kopernika w Toruniu. Jego badania koncentrują się na współczesnych literaturach francuskojęzycznych. E-mail: piotr.sadkowski@umk.pl.

1 Zob. Trevisan, Carine 1996. AURÉLIEN d'Aragon. Un «nouveau mal du siècle ». Besançon: Annales Littéraires de I'Université de Franche-Comté.

2 Zob. Aragon, Louis 1961. Aurelian. Tłumaczenie Krystyna Dolatowska. Warszawa: Państwowy Instytut Wydawniczy; Drieu La Rochelle, Pierre 1939. Gilles. Paris: Gallimard; Céline, Louis-Ferdinand 1933. Podróż do kresu nocy. Tłumaczenie Wacław Rogowicz. Warszawa: Wydawnictwo J. Przeworskiego.

3 Musset, Alfred 1979. Spowiedź dziecięcia wieku. Tłumaczenie Tadeusz Żeleński (Boy). Warszawa: Państwowy Instytut Wydawniczy. 31-32.

4 Ibid.: 31.
} 
pomiędzy przeszłością - chwalebną, lecz zniszczoną, i przyszłością - obiecującą, lecz niepewną. Pisze on: „[... nie wiadomo nigdy, czy się depce nasienie, czy zgliszcza ${ }^{5 ”}$. Są to często postacie melancholijne, trzymające się na uboczu Historii. Natomiast przeżycia ludzi powracających z Wielkiej Wojny są bardzo odmienne. Stanęli oni twarzą w twarz z brutalizacją, której próg został przekroczony w niespotykanej dotąd skali. Po raz pierwszy spotkali się z takim ogromem skrajnej przemocy i masowej śmierci. Powrót do świata „normalnie żyjących” staje się bardzo trudny. Życie wydaje się często formą utrzymywania przy życiu. Uniknęli śmierci, ale ciągle zachowują więź z tymi, którzy polegli u ich boku. Mają poczucie, że powrócili spośród zmarłych. Formuła Lost Generation po części opisuje to zjawisko. Pokolenie stracone, czyli poświęcone. Są to bardzo młodzi ludzie, którzy walczyli w imię wartości bronionych przez poprzednie pokolenie. A były to wartości dla wielu z nich niezrozumiałe. Pokolenie stracone także dlatego, że przeżyli oni pewien rodzaj depersonalizacji i derealizacji, niemożliwości odzyskania swojego miejsca w rzeczywistości i ucieczki do „sztucznych rajów”, których użycie się rozwinęło w okresie zwanym „années folles” (szalone lata dwudzieste). Na myśl tu przychodzą, obok postaci Aureliana, Gilles’a i Bardamu, bohaterowie Hemingwaya i Remarque’a, zwłaszcza w powieści Droga powrotna ${ }^{7}$.

Tytuł Pani książki opublikowanej w roku 2001, która odegrała bardzo ważną rolę w historii badań literackich nad problematyką Wielkiej Wojny, może zaskakiwać: Les fables du deuil. La Grande Guerre: mort et écriture (Fabuly żatoby. Wielka Wojna: śmierć i pisanie). Mam tu na myśli pierwszy element tytułu - słowo fables. W jakim sensie teksty literackie analizowane przez Panią Profesor są "fabułami / baśniami”"?8

C. T.: Termin fables wydawał mi się najtrafniejszy w odniesieniu do tego, co wyrażają teksty, które badałam. Mówi się zazwyczaj o „pracy” żałoby. Otóż ta praca dokonuje się poprzez historie, „fabuły”, jakie opowiadali sobie ludzie, którzy utracili ukochanych bliskich. Najpierw jest nadzieja, że ci, których zaklasyfikowano jako „zaginionych”, nie polegli. Są także słowa, które ocaleni kierują do zmarłych, tak jakby oni mogli je słyszeć. I tak np. André Pézard zwraca się do swych poległych towarzyszy: „piosenka, którą śpiewaliście już umilkła [... ] czeka się ciągle na żywy głos" ". Istnieje w tych tekstach rodzaj relacji baśniowej, dziwnej, czasami wymyślonej, jaką utrzymujemy, myślę, my wszyscy z „naszymi” zmarłymi, co też wyraźnie wykracza poza pojęcie „pracy” żałoby.

Analizowała Pani formy wyrażania żałoby zarówno $w$ utworach napisanych przez uczestników wojny, jak i w fikcjach stworzonych przez autorów należących do drugiego i trzeciego pokolenia ludzi urodzonych po wydarzeniach z lat 1914-1918. Jakie wnioski można wyciągnąć z porównania tych dwóch różnych kategorii tekstów o Wielkiej Wojnie?

\footnotetext{
5 Ibid.: 34.

6 Termin paradis artificiels zaczerpnięty z pism Charles'a Baudelaire'a, na określenie środków odurzających.

7 Zob. Remarque, Erich Maria 1956. Droga powrotna. Tłumaczenie Ludwik Szczepański. Katowice: Wydawnictwo Śląsk.

8 Trevisan, Carine 2001. Les fables du deuil. La Grande Guerre: mort et écriture. Paris: Presses Universitaires de France. Złożoność sensu tytułu wynika z wieloznaczności słowa fable w języku franuskim: zarówno „fabuła”, jak i „bajka”,,baśń".

9 Pézard, André 1918. Nous autres, à Vauquois (1915-1916). Paris: La Renaissance du Livre. 341. Książka jest uważana za jedno z najważniejszych dzieł literatury świadectwa tworzonej przez uczestników I wojny.
} 
C. T.: W utworach autorów z drugiego i trzeciego pokolenia (a więc w tekstach współczesnych) interesujący i poruszający jest wysiłek podejmowany przez potomków, by przyjąć nieszczęście i to, co nie zostało wypowiedziane przez przodków. To także wysiłek, aby wyobrazić sobie, czym mogła być katastrofa, którą rozpoczął się wiek XX. Strategie pisania $\mathrm{w}$ tych tekstach są bardzo różne. Albo jest to praca na podstawie rodzinnych archiwów, albo wykorzystywanie wojny jako podstawy do wyobrażania sobie aktów skrajnej przemocy, albo też są to opowieści filiacyjne, w których narrator przedstawia siebie jako człowieka, którego tożsamość wywodzi się z doświadczenia tej przemocy. Ciekawe jest pytanie, dlaczego ta wojna, ponad sto lat później, inspiruje tak dużo tekstów. Bez wątpienia dlatego, że przez wiele lat była przyćmiona przez okropieństwa II wojny światowej.

W przedmowie do Pani książki Pierre Pachet stwierdza, że „Carine Trevisan pisze powodowana niepokojem, troską, utrapieniem, a nawet smutkiem, i to smutkiem bardzo osobistym, związanym z żałobą, niemożliwą żałobą, ale także smutkiem zbiorowym i historycznym, gdyż lączy się on z przerażającą masakrą setek tysięcy ludzi podczas I wojny. Ten smutek jeszcze nie wygasł, ciągle trwa, daje się odczuć bezgłośnie albo niespodzianie, poprzez nieoczekiwane nawroty"10. Czy te słowa nadal, w przededniu setnej rocznicy rozejmu, są aktualne? Czy też przeciwnie, dzięki rozlicznym pracom naukowym, tekstom literackim, dziełom artystycznym i innym formom upamiętniania, od ostatnich lat $\mathrm{XX}$ wieku po dzień dzisiejszy, francuska żaloba już się dokonała?

C. T.: Nie potrafię odpowiedzieć na to pytanie. Zastanawiam się dzisiaj nad problemem przyszłych żałób, zwłaszcza po śmierci uchodźców na Morzu Śródziemnym, po syryjskich rodzinach, po masakrach w Somalii. Wydaje mi się, że obecnie nasza historia zbudowana jest tylko $\mathrm{z}$ wielu trudnych żałób.

Pani badania nad Wielką Wojną w literaturze odznaczają się interdyscyplinarnością. Interesuje się Pani Profesor, na przykład, przedstawianiem w tekście doświadczeń sensorycznych ${ }^{11}$, albo łączeniem ekspresji literackiej z dyskursem psychiatrycznym w Podróży do kresu nocy Céline'a ${ }^{12}$. Jeśli badania literaturoznawcze poświęcone tematyce wojennej będą nadal rozwijać się $w$ wymiarze interdyscyplinarnym, jakie aspekty pisarstwa francuskiego $w$ tym kontekście warto jeszcze zgłębić?

C. T.: Chciałabym, by autorzy francuscy (lub inni) zajęli się problemem terroryzmu we Francji. Mam bardzo młodych studentów, którzy interesują się wojną algierską. Należą oni do drugiego pokolenia żyjącego po tych wydarzeniach. Ich prace, dotyczące tekstów francuskich (ale nie tylko), są ze wszech miar interdyscyplinarne: pomiędzy historią, kinem i literaturą. Myślę, że mają odpowiednią wrażliwość, by zajmować się zjawiskiem wojennych doświadczeń sensorycznych.

10 Pachet, Pierre 2001. „Préface. Un chagrin sans fin”. W: Carine Trevisan. Les fables du deuil. La Grande Guerre: mort et écriture. Paris: Presses Universitaires de France. IX.

11 Trevisan, Carine 2009. "Le bruit de la guerre". W: Stéphane Audoin-Rouzeau, Esteban Buch, Myriam Chimènes, Georgie Durosoir (red.). La Grande Guerre des musiciens. Lyon: Symétrie. 5-15.

12 Trevisan, Carine 1996. „De l'aveu au témoignage. Le discours psychiatrique dans Voyage au bout de la nuit”. Littérature 104 : 57-73. 
W roku 2005 przyczyniła się Pani Profesor do ponownego odkrycia jednego $\mathrm{z}$ najbardziej wyjątkowych świadectw $\mathrm{z}$ czasów Wielkiej Wojny, wydanego $\mathrm{w}$ roku 1917: La Sainte Face (Święte Oblicze) Élie'ego Faure'a. Czy mogłaby Pani przybliżyć naszym czytelnikom ten tekst, do którego napisała Pani wstęp, postrzegany dzisiaj jako niewygodny i wymykający się ocenie? Na czym polega oryginalność formy literackiej i refleksji autora - wojskowego lekarza na froncie I wojny i wybitnego historyka sztuki ${ }^{13}$

C. T.: Czytając Élie’ego Faure’a, byłam zbita z tropu. Jest to tekst bardzo dobrze napisany, ale zawarte w nim poglądy na temat wojny jako zjawiska regulacji biologicznej (silni zabijają słabych) są bardzo zaskakujące. Nie rozumiałam jak osoba, która napisała pomnikową historię sztuki, dzieło tak subtelne, mogła głosić podobne rzeczy. Potem byłam poruszona precyzyjnością opisów (Faure posiadł sztukę detalu), odwagą autora (który poprosił o ponowne wysłanie go na front), jego wnikliwością. Élie'ego Faure’a zmuszano do przeprowadzania przerażających operacji (mimo że nie był chirurgiem). W swoim tekście zachowuje on wysoką staranność pisarską, uwagę, czym odznacza się na tle zwyczajowych świadectw z Wielkiej Wojny. Ten utwór jest dzisiaj rzadko czytany, właśnie z powodu zaskakującej formy, pełnej czasami trochę niestrawnych dygresji.

Praca zbiorowa, opublikowana w roku 2016, którą Pani współredagowała z Hélène Baty-Delalande, Entrer en guerre (Pójść na wojnę), jest wynikiem konferencji zorganizowanej na Uniwersytecie Paris VII - Denis Diderot z okazji setnej rocznicy wybuchu I wojny. Oczywiście tematyka Wielkiej Wojny dominuje wśród zebranych w tomie studiów wielodyscyplinarnych. Jednakże analizy dotyczące I wojny sąsiadują tam $z$ artykułami dotyczącymi zjawiska wojny $w$ innych okresach historycznych, począwszy od starożytności ${ }^{14}$. Jaka była wspólna myśl przewodnia badań nad wojną $\mathrm{w}$ różnorodnych kontekstach? Jakie wnioski można wyciągnąć $\mathrm{z}$ zaproponowanych w tomie perspektyw synchronicznych i diachronicznych, na temat szczególnego miejsca Wielkiej Wojny w historii i kulturze?

C. T.: Koncepcja tej pracy polegała na obserwacji form, jakie może przyjmować zjawisko „pójścia na wojnę” w różnych okresach i cywilizacjach. Z mojej strony, jeśli chodzi o rok 1914, zauważyłam, że przed tym wydarzeniem zdarzały się entuzjastyczne podejścia do rozpoczęcia wojny (w Rzymie albo w czasie wojen rewolucyjnych). Nie odnotowałam, przed Wielką Wojną, wśród badaczy zainteresowania zjawiskiem „deflacji”, tzn. konfrontacji pomiędzy wyobrażeniem wojny a wojną realną. Filmoznawcy kładli nacisk na brutalność szkolenia żołnierzy amerykańskich. Ale są to badania pozostające na pograniczu tematyki doświadczenia wojennego.

\footnotetext{
13 Faure, Élie 2005. La Sainte Face suivi de Lettres de la Première Guerre Mondiale. Édition préfacée par Carine Trevisan. Paris: Bartillat.

14 Zob. Baty-Delalande, Hélène et Carine Trevisan (red.) 2016. Entrer en guerre. Paris: Hermann.
} 